\title{
Effects of Sex Steroid Receptor Specificity in the Regulation of Skeletal Metabolism
}

\author{
T. F. Tözüm, ${ }^{1,2}$ M. E. Oppenlander, ${ }^{1,3}$ A. J. Koh-Paige, ${ }^{1}$ D. M. Robins, ${ }^{3}$ L. K. McCauley ${ }^{1,4}$ \\ ${ }^{1}$ Department of Periodontics/Prevention/Geriatrics, School of Dentistry, University of Michigan, Ann Arbor, Michigan, USA \\ ${ }^{2}$ Department of Periodontology, Faculty of Dentistry, Hacettepe University, Ankara, Turkey \\ ${ }^{3}$ Department of Human Genetics, Medical School, University of Michigan, Ann Arbor, Michigan, USA \\ ${ }^{4}$ Department of Pathology, Medical School, University of Michigan, Ann Arbor, Michigan, USA
}

Received: 22 May 2003 / Accepted: 2 December 2003 / Online publication: 25 March 2004

\begin{abstract}
The interaction between estrogens and androgens, with their protective effects in bone, and parathyroid hormone (PTH), a calcitropic peptide hormone, is complex but may be better understood with murine models. The purpose of this study was to characterize skeletal phenotypes of mice deficient in estrogen receptor alpha $(\mathrm{ER} \alpha)$, androgen receptor (AR, mutant $\mathrm{tfm}$ ), or both, and determine if ER $\alpha$ and AR alter osteoblast differentiation and/or PTH response in vitro. Loss of $E R \alpha$ resulted in increased long bone length in females, but reduced length in males, suggesting loss of $E R \alpha$ reversed sex steroid-dependent skeletal dimorphism. The AR deficient $t f m$ mice (genetically male but phenotypically female) had the longest bones and, similar to males, lengths were reduced with loss of ER $\alpha$. Loss of $A R$ and/or $E R \alpha$ resulted in a reduction in femoral bone mineral density (BMD) compared to male wildtype (WT) mice, suggesting $\mathrm{t} f \mathrm{~m}$ mice follow the female sex for BMD. In males or $\mathrm{tfm}$ mice, but not females, loss of AR and/or ER $\alpha$ caused a reduction in cortical width of the tibia compared to male WT mice. Reduced trabecular bone was found in tibiae of female and $\mathrm{tfm}$ mice versus male littermates, suggesting that $\mathrm{tfm}$ mice follow the female sex for trabecular bone but loss of ER $\alpha$ did not alter trabecular bone levels. Primary calvarial osteoblasts of male WT mice were less responsive to PTH stimulation of cAMP than all other genotypes, suggesting the female chromosomal sex and/ or loss of $E R \alpha$ or AR results in increased sensitivity to PTH. In conclusion, $t \mathrm{fm}$ mice follow the male pattern of long bone development, but imitate females in bone density and trabecular bone. Loss of ER $\alpha$ and/or AR results in increased osteoblast sensitivity to PTH and may explain actions of PTH noted in hypogonadal humans.
\end{abstract}

Key words: Bone - Osteoblast - Estrogen - Estrogen receptor - Androgen - Androgen receptor - Parathyroid hormone

Correspondence to: L. K. McCauley; E-mail: mccauley@ umich.edu
It is well accepted that estrogen deficiency is a major risk factor for osteoporosis but the role of estrogen and androgen receptors in skeletal metabolism is not as clear. Hypogonadism and delayed puberty contribute to osteopenia in men and women [1-4]. Osteoporosis in hypogonadal males is associated with low plasma testosterone, estradiol and androstenedione concentrations which correlate with reduced bone density [5]. One case of a man with a mutant estrogen receptor and several cases of humans with aromatase deficiency confirm that estrogen and the estrogen receptor are critical for skeletal homeostasis; however, the mechanisms involved are poorly understood [6-8]. Recent evidence suggests that actions of sex steroids in bone may be via different mechanisms than those that impact reproductive organs [9].

Parathyroid hormone (PTH), unlike sex steroids, is a calcitropic peptide hormone that acts directly on the skeleton to promote calcium release and on the kidney to enhance calcium reabsorption via the $\mathrm{PTH}-1$ receptor (PTH-1R). PTH has both catabolic and anabolic actions in bone [10]. Recent interest has been focused on its anabolic actions due to its therapeutic potential. Intermittent PTH causes an increase in vertebral, femoral and total body mineral density in postmenopausal osteoporosis [11]. On the other hand, infusion of PTH in vivo is catabolic via increased osteoclast numbers [12]. Interestingly, suppression of sex steroids increases the skeletal responsiveness to the bone-resorbing activities of PTH in elderly men [13].

The PTH-1R was the first PTH receptor isolated, cloned and sequenced, and is present in high numbers on osteoblasts [14]. The estrogen receptor $\alpha(\mathrm{ER} \alpha)$ and androgen receptor (AR) are also expressed in osteoblasts $[15,16]$. Functional effects of androgens on osteoblastic cell proliferation and alkaline phosphatase have been described [17]. Furthermore, androgens, as well as estrogens, act directly on human bone cells to selectively modulate early effects of PTH $[18,19]$. Still, 
relationships between PTH and sex steroids are unclear.

To better understand the effects of estrogens, androgens, and their receptors in the skeleton, animal models of receptor deficiency are valuable tools. The testicular feminized male $(\mathrm{t} f \mathrm{~m})$ mouse has a single point mutation in the AR that inactivates the receptor resulting in a genetically male mouse with a female phenotype [20, 21]. The AR is considered necessary for full skeletal growth and it has been suggested that a modest increase in estrogens in androgen-resistant animals may prevent cancellous bone loss [22]. Genetic models of estrogen receptor dysfunction have been generated and loss of the $\mathrm{ER} \alpha$ appears to impact the skeleton more dramatically than the $\operatorname{ER} \beta[23,24]$.

The purpose of this study was to characterize the skeletal phenotypes of ER $\alpha, \mathrm{AR}$ and combined ER $\alpha$ / AR knockout mice and to determine whether ER $\alpha$ and AR regulate osteoblast differentiation in vitro. Further, whether these receptors are necessary for actions of PTH on osteoblasts in vitro was determined.

\section{Materials and Methods}

\section{Generation of ER and AR Mutant Mice}

The generation of the ER $\alpha$ mutant mice has been described previously [25]. Heterozygous ER $\alpha+/-$ male and female mice were crossed to yield a Mendelian distribution of $\mathrm{ER} \alpha+/+$, $+/-$ and $-/-$ mice. Genotyping of tail-biopsy DNA was performed by PCR using standard protocols as described [25]. $\mathrm{Tfm}$ carrier female mice were obtained from the Jackson Laboratory (Bar Harbor, Maine, USA). Tfm carrier females were crossed with tabby males (The Jackson Laboratory) to continue producing $\mathrm{t} f \mathrm{~m}$ carriers used to obtain $\mathrm{tfm}$ mice. In order to generate $t f m$ ER $\alpha$-/-mice, male ER $\alpha+/-$ mice were crossed with $t \mathrm{fm}$ carrier females. The resulting ER $\alpha+/-t \mathrm{fm}$ carrier females were crossed with male $\mathrm{ER} \alpha+/-$ mice to get mice with the desired genotypes. Male and female littermates were used as controls. All studies were approved by the Institutional Animal Care and Use Committee at the University of Michigan.

\section{Gross Evaluation and Microradiographic Analysis}

The length and width of femurs and tibiae were measured using an electronic digital caliper (Max-Cal, MFG. Co., Ltd, Japan) with length reported as the longest measurement from proximal to distal and the width as the narrowest measurement at the mid-diaphyseal region. Femurs were evaluated using a microradiography system (Faxitron X-ray Corporation, IL, USA).

\section{Dual Energy X-ray Absorptiometry (DEXA)}

Mice were sacrificed at 4 and 12 weeks of age, and femurs and tibiae were dissected and placed in 70\% ethanol for DEXA and $10 \%$ formalin for histomorphometry. Areal bone mineral density (BMD) and bone mineral content (BMC) were measured with the Norland pDEXA Sabre (Fort Atkinson, WI, USA) using the Sabre Small Animal Research software (version 2.2.4) as previously described [26].

\section{Bone Histomorphometry}

Tibias and lumbar vertebrae from mice were trimmed of musculature, fixed in $10 \%$ formalin at $4^{\circ} \mathrm{C}$, decalcified in $10 \%$ EDTA ( $\mathrm{pH}$ 7.4) for 7 days and embedded in paraffin. Longitudinal sections of tibiae and vertebrae were cut at $5 \mu \mathrm{m}$ and stained with hematoxylin and eosin for histological evaluation. Histomorphometric analysis of the lumbar vertebrae and tibiae were performed using a computer-assisted bone histomorphometric analyzing system (Image-Pro Plus version 4.0, Media Cybernetics, MD, USA) as described [26]. Lumbar vertebrae measurements included total area (Tt.Ar.), and percent of trabecular bone area (Tb.Ar./Tt.Ar.). Measurements of the proximal tibia were performed as described for vertebrae and also included cortical bone width (Ct.Wi.) (10 measures of cortical width taken at the mid-diaphysis were averaged for each tibia), osteocyte number (N.Ot. $/ \mathrm{mm}^{2}$ ) and extension of trabeculae from the growth plate as percent of trabecular length (Tb.Le./Tt.Le) [27].

\section{Bone Ashing and Calcium Assay}

Femurs were isolated, dried at $110^{\circ} \mathrm{C}$ overnight and weighed. Bones were then ashed at $800^{\circ} \mathrm{C}$ for 4 hours, weighed again, dissolved in $500 \mu \mathrm{l} 6 \mathrm{~N} \mathrm{HCl}$, and amount of calcium was determined by colorimetric assay with cresolphthalein complexone (Sigma, St. Louis, MO, USA). Total calcium was expressed as percent of ash weight.

\section{Isolation of Primary Calvarial Osteoblasts and Cell Culture}

Primary calvarial cells were isolated as previously described [28]. Briefly, calvaria of 12 week mice were dissected, isolated from periosteum and subjected to sequential digestion of 20 , 40 and 90 minutes in collagenase $\mathrm{A}(2 \mathrm{mg} / \mathrm{ml}$, BoehringerMannheim, Indianapolis, IN, USA) with $0.25 \%$ trypsin (Invitrogen, Grand Island, NY, USA). Cells from the third digestion were washed, counted, and plated in phenol red-free $\alpha$ MEM (Invitrogen) with $10 \%$ charcoal/dextran treated fetal bovine serum (HyClone, Logan, Utah, USA) containing 100 units $/ \mathrm{ml}$ of penicillin and $100 \mu \mathrm{g} / \mathrm{ml}$ streptomycin. Medium was changed every other day. Primary cultures without passage were used for adenylyl cyclase stimulation and osteoblast differentiation assays.

\section{Adenylyl Cyclase Stimulation Assay}

The adenylyl cyclase stimulation and cAMP-binding protein assay were performed as previously described with minor modifications [29]. Cells were plated in triplicate at 40,000 cells/ $\mathrm{cm}^{2}$ into 24-well plates and adenylyl cyclase stimulation assay was performed on day 7 to optimize PTH-1R expression [28]. Cells were then stimulated with $10^{-8} \mathrm{M}$ human PTH (hPTH) (134) (Bachem, Inc., Torrance, CA, USA), $10^{-7}$ M 17- $\beta$ estradiol (Sigma, St. Louis, MO, USA), or vehicle, in calcium and magnesium-free Hanks' Balanced Salt Solution (Life Technologies, Carlsbad, CA, USA) containing $0.1 \%$ bovine serum albumin and $1 \mathrm{mM}$ isobutylmethylxanthine at $37^{\circ} \mathrm{C}$ for 15 minutes. After aspirating the medium, the cAMP was extracted by adding $250 \mu \mathrm{l} /$ well ice-cold $5 \%$ perchloric acid and incubating overnight at $-20^{\circ} \mathrm{C}$. After thawing, the $\mathrm{pH}$ was adjusted to 7.5 with $4 \mathrm{~N} \mathrm{KOH}$, and the neutralized extract was then assayed for cAMP using a cAMP-binding protein assay [29].

The cAMP binding assay was performed by incubating $\left[{ }^{3} \mathrm{H}\right]-$ cAMP (ICN, Irvine, CA, USA) with standards or unknowns and a cAMP-binding protein sufficient to bind $40-60 \%$ of radioactivity for 90 minutes on ice. Dextran-coated charcoal was added for 20 minutes and centrifuged to remove unbound from bound cAMP-binding protein- $\left[{ }^{3} \mathrm{H}\right]$-cAMP complexes. The radioactivity of the supernatants was determined with a liquid scintillation counter and cAMP levels calculated by the loglogit method using the Graph Pad Prism program. The cAMP 
Table 1. Gross evaluation of femur and tibia: ER $\alpha$ and AR on 12-week-old mutant mice [mean (mm) \pm SEM (n)]

\begin{tabular}{llll}
\hline Genotype & Femur length & Tibia length & Femur width \\
\hline Female ER $\alpha+(12)$ & $15.27 \pm 0.14$ & $17.92 \pm 0.18$ & $1.21 \pm 0.01$ \\
Female ER $\alpha-(16)$ & $15.60 \pm 0.17$ & $18.56 \pm 0.15 \S$ & $1.21 \pm 0.01$ \\
Male ER $\alpha+(17)$ & $15.56 \pm 0.13$ & $18.47 \pm 0.08 \S$ & $1.25 \pm 0.02$ \\
Male ER $\alpha-(11)$ & $15.08 \pm 0.12^{*}$ & $18.21 \pm 0.08$ & $1.33 \pm 0.04^{*}$ \\
tfm ER $\alpha+(11)$ & $16.04 \pm 0.09^{* \dagger}$ & $18.83 \pm 0.09^{* \dagger}$ & $1.17 \pm 0.03$ \\
tfm $\mathrm{ER} \alpha-(10)$ & $15.19 \pm 0.26^{\dagger}$ & $18.40 \pm 0.15 \dagger$ & $1.18 \pm 0.03$ \\
\hline
\end{tabular}

${ }^{*} \mathrm{p}<0.05$ vs male $\mathrm{ER} \alpha+, \dagger \mathrm{p}<0.05$ vs $t \mathrm{fm} \mathrm{ER} \alpha+, \dagger \mathrm{p}<0.001$ vs female $\mathrm{ER} \alpha+$, p $<0.05$ vs male $\mathrm{ER} \alpha-$, \$p $<0.05$ vs female $\mathrm{ER} \alpha+$

levels were standardized to cell numbers obtained by trypan blue enumeration of parallel triplicate wells.

\section{Mineralization Assays}

Primary osteoblasts from mice of each genotype were plated in $60 \mathrm{~mm}$ plates and medium was changed every other day. At day 7 , plates were treated with mineralization media [ascorbic acid $(50 \mu \mathrm{g} / \mathrm{ml})+\beta$-glycerophosphate $(10 \mathrm{mM})]$ for 21 days. Cells were then fixed with $95 \%$ ethanol and stained with silver nitrate by the Von Kossa method to detect phosphate deposits in bone nodules [30], Bone nodules were analyzed morphometrically by scanning five random sites from each plate using Image-Pro Plus version 4.0. Values of mineralized nodule number per area and area of mineralization per area were calculated for primary cultures from each mouse and averaged with values from mice with the same genotype.

\section{Statistical Analysis}

The results of multiple experiments were analyzed using ANOVA followed by a Tukey-Kramer multiple comparison test and Student's $t$ test with the Instat 2.1 biostatistics program (GraphPad Software).

\section{Results}

Gross Evaluation and Microradiographic Analysis

Mutations in ER have been speculated to be responsible for delay in epiphyseal closure, which increases long bone length [6]. To understand the impact of ER $\alpha$ and/ or AR in long bone development, 4- and 12-week-old tfm mice with their female and male littermates were evaluated. Gross evaluation of femurs revealed that in 12-week-old mice, loss of ER $\alpha$ resulted in reduced femur length in males. The $t f m \mathrm{ER} \alpha+/+$ mice had the greatest femur length, and similar to males, lengths were reduced with loss of $\mathrm{ER} \alpha$ (Table 1). In contrast, loss of ER $\alpha$ caused an increase in tibia length in females.

There was a $23 \%$ increase in femur length of female and male mice during the period of growth from 4 to 12 weeks. The $t \mathrm{fm}$ mice had a similar but slightly lower $22 \%$ increase in femur length during this time period. In contrast, the tibiae lengths increased only 14 and $16 \%$ in female and males, respectively, and $15 \%$ in $\mathrm{tfm}$ mice between 4 and 12 weeks (data not shown). These data suggest that sex steroids that are typically produced increasingly from the age of 4 wks in mice may impact femur growth more than tibia growth. This appears to
Table 2. Femur and tibia BMD: ER $\alpha$ and AR mutant mice, 12-week-old, mean $\left(\mathrm{g} / \mathrm{cm}^{2}\right) \pm \operatorname{SEM}(\mathrm{n})$

\begin{tabular}{lll}
\hline Genotype & Femur BMD & Tibia BMD \\
\hline Female ER $\alpha+(12)$ & $0.029 \pm 0.0004^{*}$ & $0.026 \pm 0.0003$ \\
Female ER $\alpha-(16)$ & $0.028 \pm 0.0006$ & $0.026 \pm 0.0011$ \\
Male ER $\alpha+(17)$ & $0.032 \pm 0.0010$ & $0.026 \pm 0.0006$ \\
Male ER $\alpha-(11)$ & $0.030 \pm 0.0004^{*}$ & $0.025 \pm 0.0002^{*}$ \\
tfm $\mathrm{ER} \alpha+(11)$ & $0.029 \pm 0.0005^{*}$ & $0.025 \pm 0.0004$ \\
tfm $\mathrm{ER} \alpha-(10)$ & $0.028 \pm 0.0005^{*}$ & $0.025 \pm 0.0006$ \\
\hline
\end{tabular}

$* \mathrm{p}<0.05$ vs. male ER $\alpha+$

be true for male and $\mathrm{tfm}$ mice, both of which demonstrated significant reductions in femur length with loss of the ER $\alpha$ but nonsignificant or only mildly significant reductions in tibia length. In contrast, the trend towards increased long bone length with loss of ER $\alpha$ in females was significant in tibia but not femurs.

\section{Dual X-ray Absorptiometry}

Developmental studies have tried to explain the role of sex steroid receptors in the skeleton. The impact of ER $\alpha$ was reported in orchidectomized male mice where it was proposed that AR had a significant role as well as ER $\alpha$ [31]. To clarify the impact of these receptors on bone content, BMD and BMC were measured on whole femurs and tibias for all mice. Younger mice (4 weeks) demonstrated a significant increase in BMD in $\mathrm{tfm}$ $\mathrm{ER} \alpha+/+$ compared to $\mathrm{ER} \alpha+/+$ males and females (data not shown). However, at 12 weeks of age the female gender and loss of $\mathrm{ER} \alpha$ and/or AR resulted in a reduction in BMD for femurs compared to male WT mice. Further, absence of ER $\alpha$ in tibiae resulted in a statistical reduction of BMD in males (Table 2). When comparing between 4 and 12 weeks of age, femur BMD increased $13 \%$ in males but only $3 \%$ in females, suggesting that males may be more susceptible to hormonal changes during this period of growth.

\section{Bone Histomorphometry}

Previous reports of bone histomorphometry in $\mathrm{tfm}$ rats indicated no differences in cancellous bone volume of 


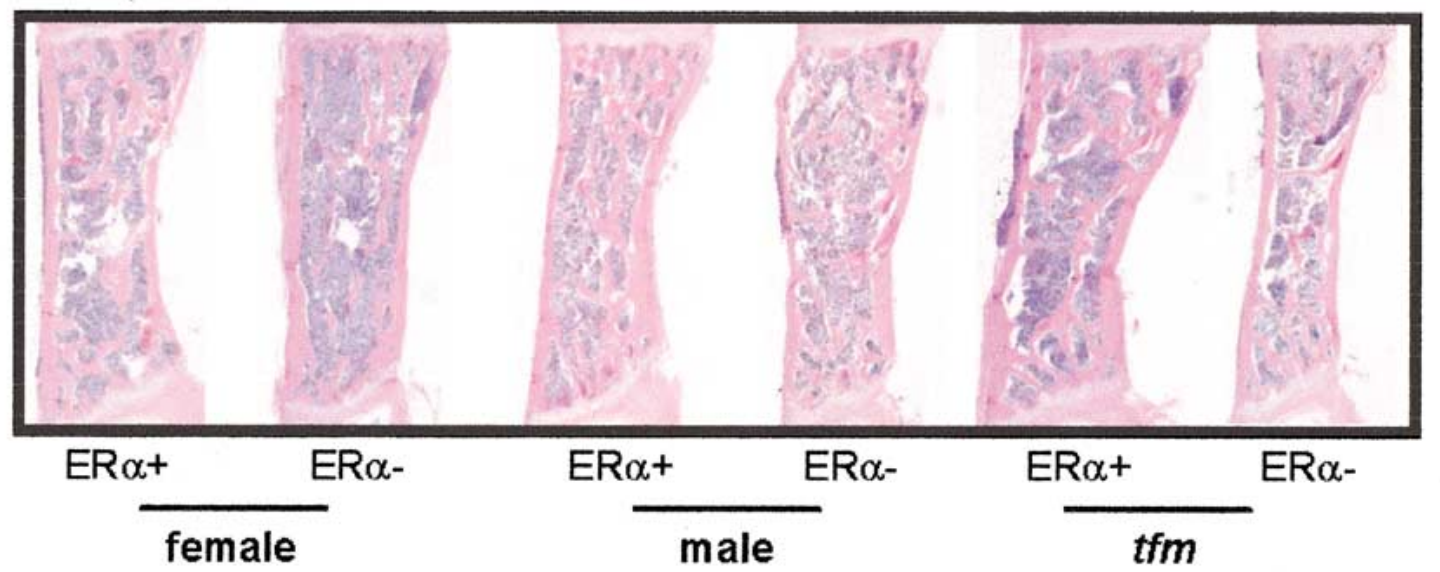

B

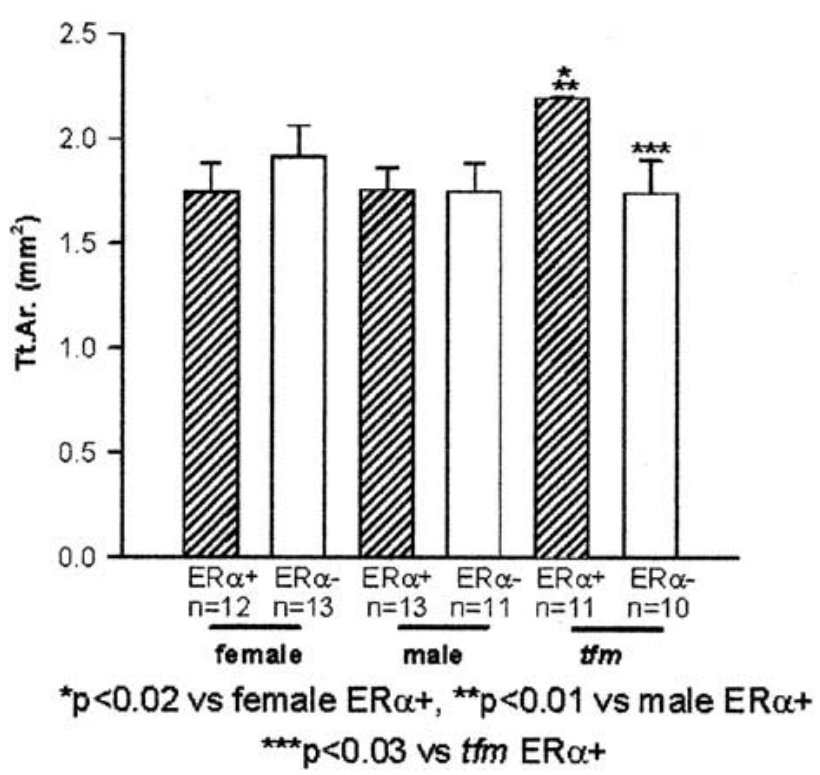

Fig. 1. Bone histomorphometry of vertebrae. (A) Representative lumbar vertebra from each of the six genotypes, (B) total bone area and $(\mathbf{C})$ trabecular bone area expressed as percent of total bone. Data are expressed as means \pm SEM. The $t f m$

the proximal tibia compared to normal female and male rats, suggesting that the AR is not critical for bone volume [22]. In contrast, $\mathrm{ER} \alpha$ was shown to protect trabecular bone development in gonadectomized male mice suggesting the $E R \alpha$ has protective effects in the skeleton [31]. Accordingly then, the ER $\alpha$ and AR would appear to have different effects on the skeleton. Static histomorphometric analysis of lumbar vertebrae indicated that $\mathrm{tfm}$ mice had the greatest overall vertebral area and loss of ER $\alpha$ in the $t f m$ background, resulting in a reduction in total vertebral area (Fig. 1A, B). A significant reduction in trabecular area of the vertebrae was

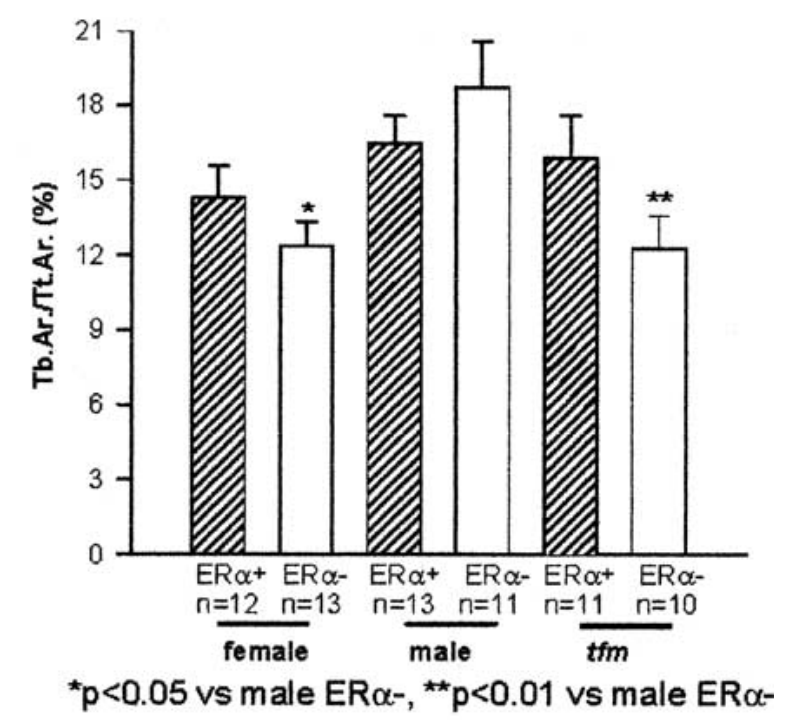

mice had the greatest overall vertebral size, and loss of ER $\alpha$ in the $t f m$ background resulted in a reduction in vertebral size. Trabecular bone area was reduced in the absence of ER $\alpha$ in female and $\mathrm{tfm}$ mice compared to males.

noted in the absence of ER $\alpha$ in female and $t \mathrm{fm}$ mice compared to male $\mathrm{ER} \alpha$ mice but not when compared to same gender wildtype mice (Fig. 1C).

Histomorphometry of the proximal tibias showed reduced trabecular bone for female mice compared to males. Tfm $\mathrm{ER} \alpha+/+$ mice had similar trabecular bone as females and also had reduced trabecular bone compared to male $\mathrm{ER} \alpha+/+$ mice. Loss of ER $\alpha$ in the $\mathrm{tfm}$ mice did not alter bone area versus the $t f m$ ER $\alpha+/+$ but bone area was reduced compared to ER $\alpha-/-$ males (Fig. 2). When evaluating the extension of trabecular bone into the diaphysis, a similar pattern emerged. Male 


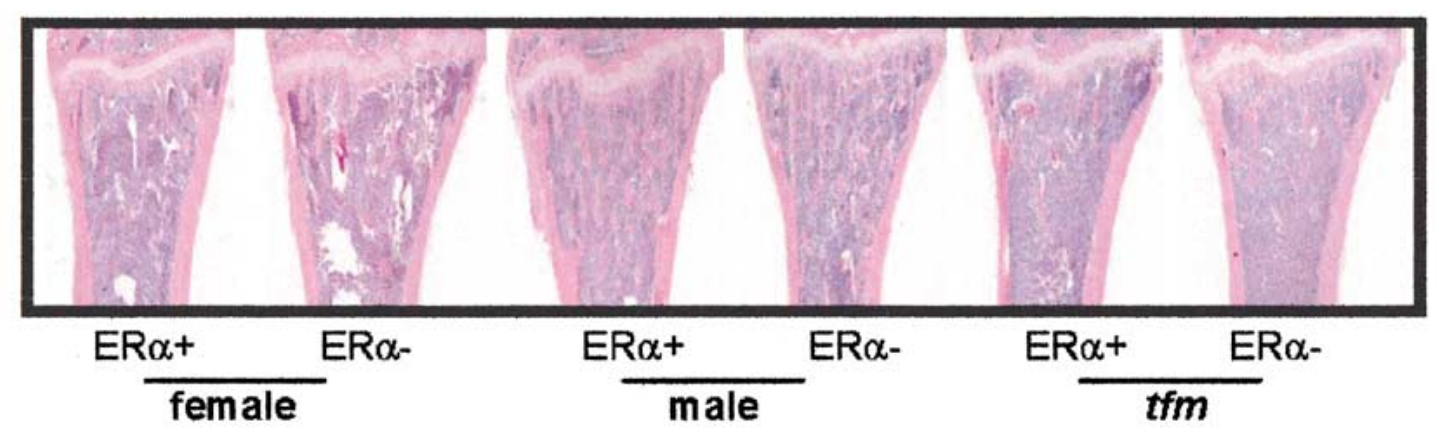

B

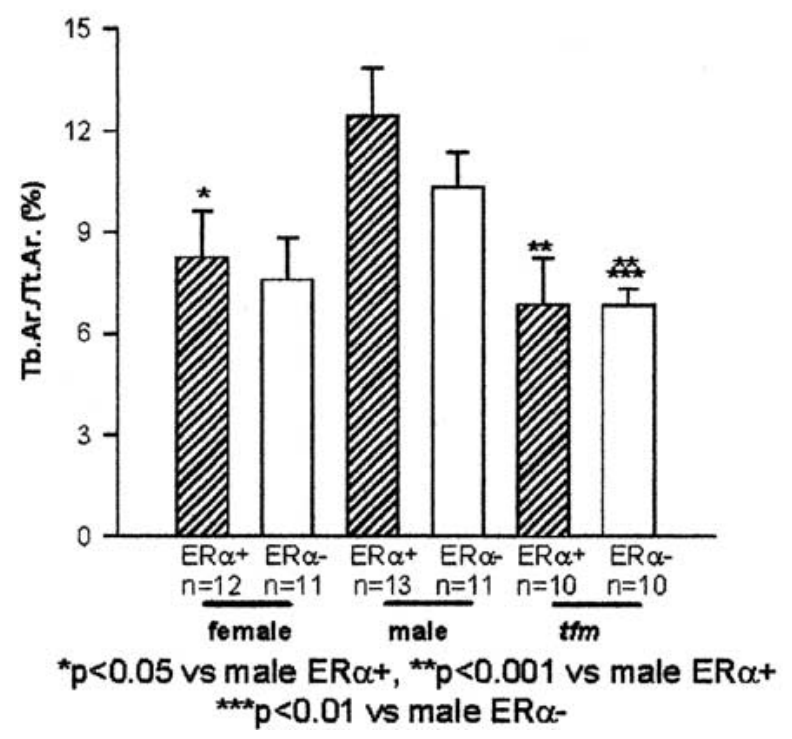

Fig. 2. Bone histomorphometry of proximal tibia. (A) Representative sections of proximal tibia from each of the six genotypes, (B) trabecular bone area expressed as percent of total bone and $(\mathbf{C})$ trabecular bone length (measure of the distance trabeculae extend from the growth plate into the di-

$\mathrm{ER} \alpha+/+$ or $-/-$ mice had increased extension of trabeculae as compared to its $t \mathrm{fm}$ or female counterpart.

Male mice had the greatest tibial cortical width of all genotypes (Fig. 3). Loss of $\mathrm{ER} \alpha$ and/or AR caused significant reduction in the cortical width of males, but compared to females or $\mathrm{tfm}$ mice, the male ER $\alpha-/-$ cortical width was still higher. Osteocyte density followed a similar trend, with the lowest density found in the tibial cortical bone of female WT mice, whereas $t \mathrm{fm}$ $\mathrm{ER} \alpha+/+$ mice had the highest number of osteocytes.

\section{Bone Ashing and Calcium Assay}

The femoral ashweight generally paralleled the BMD levels found, with the exception that no significant dif-

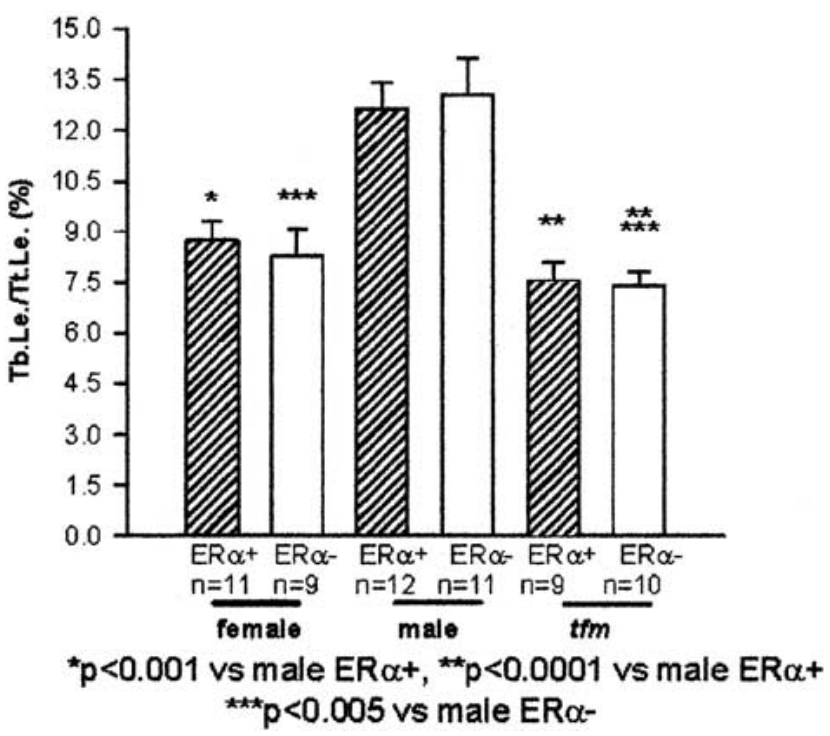

aphysis) presented as a percent of the total length of tibia. Values are given as means \pm SEM. Trabecular bone area and trabecular bone lengths were decreased for female and $\mathrm{tfm}$ tibiae compared to male mice, suggesting the $t f m$ mice follow the female gender for tibial trabecular bone.

ference was noted in the $t \mathrm{fm}$ ER $\alpha+/+$ versus the male ER $\alpha+/+$ (Fig. 4). Moreover, there was no significant difference in total calcium amount and total calcium expressed as percent of ashweight for femurs amongst any genotypes (data not shown) suggesting that there were no alterations in the calcium incorporation in bone.

\section{Mineralization Assay}

Many studies have reported that estrogens and/or androgens alter osteoblast differentiation [17, 32]. In the present study, we found no significant alterations in the mineralized nodule number or area for any osteoblastic cultures from the various genotypes after 21 days of in 


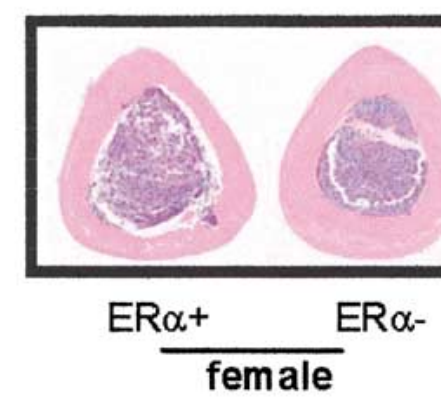

B

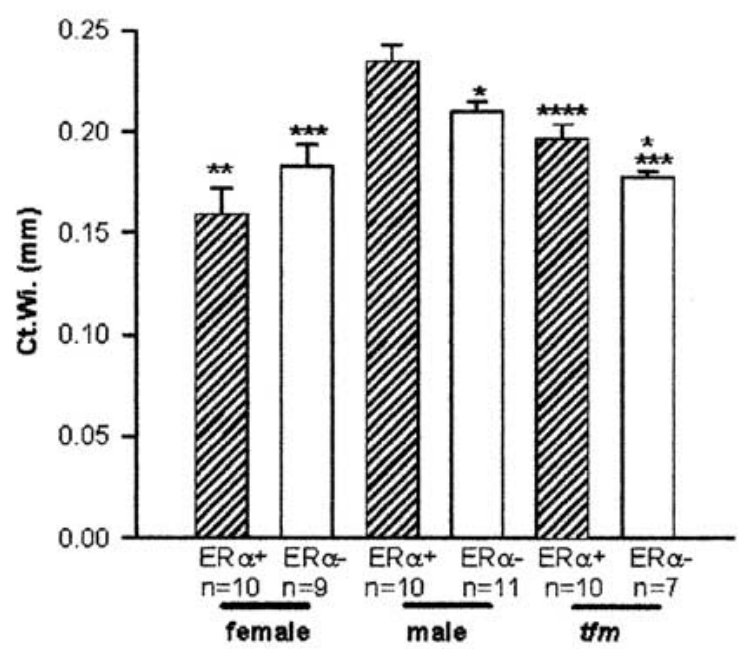

${ }^{*} p<0.02$ vs male ER $\alpha+,{ }^{* \star} p<0.0001$ vs male ER $\alpha+$ *** $p<0.05$ vs male ER $\alpha$-,

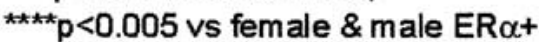

Fig. 3. Cortical bone of the tibia. (A) Representative photos of cortical bone from mid-diaphysis of tibiae from each of the six genotypes, (B) cortical width of tibiae and (C) number of osteocytes $/ \mathrm{mm}^{2}$ cortical bone. Data are expressed as means \pm SEM. Loss of ER $\alpha$ and/or AR caused a reduction in cor-

vitro differentiation (data not shown). These data suggest that neither ER $\alpha$ nor AR is necessary for normal differentiation and mineralization in vitro.

\section{Adenylyl Cyclase Stimulation Assay}

PTH binds to the PTH-1R and activates adenylyl cyclase, which leads to increased cAMP production [14]. Recently it has been demonstrated that estrogens stimulate surface receptors, activate adenylyl cyclase, and stimulate cAMP production $[33,34]$. To verify this effect in primary osteoblasts, $17-\beta$ estradiol was tested for its ability to stimulate adenylyl cyclase in a manner similar to PTH. The hPTH (1-34) and 17- $\beta$ estradiol-treated cAMP levels were calculated relative to cell numbers and basal cAMP levels.

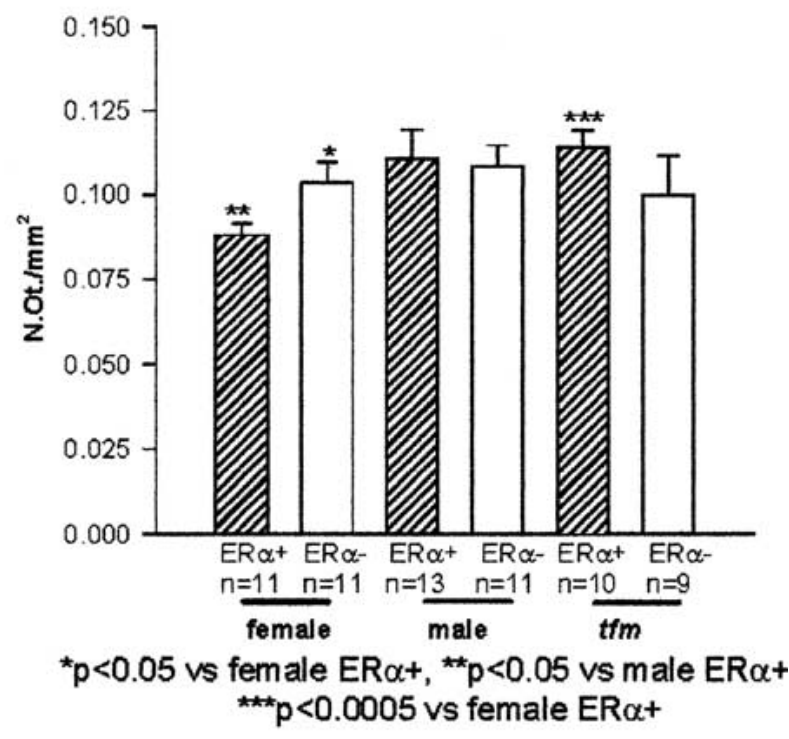

tical width of tibia compared to male WT where female mice had also reduced cortical width but loss of the ER $\alpha$ did not alter cortical width in female tibia. Further, loss of ER $\alpha$ or AR increased the numbers of osteocytes per area of cortical bone in female tibiae.

Results indicated a 1.5 to 2.5 -fold increase in cAMP levels with $17-\beta$ estradiol but no significant difference among genotypes (data not shown). All groups demonstrated dramatic (40-200-fold) cAMP elevation following hPTH (1-34) stimulation that reflected the biological activity of PTH-1R in primary osteoblasts (Fig. 5). Cells from female WT mice had increased PTH-stimulated cAMP levels compared to male WT where the absence of ER $\alpha$ and/or AR resulted in increased ability for PTH to elevate cAMP levels.

\section{Discussion}

Sex steroids exert several physiological effects on skeletal metabolism, including effects on longitudinal bone 


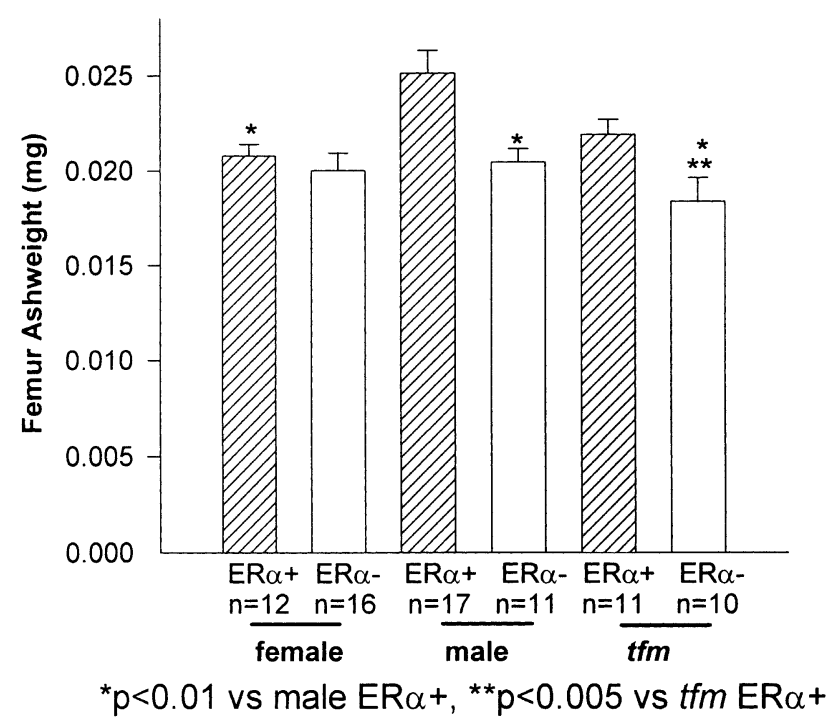

Fig. 4. Ash weight of femurs from 12-old wk mice. Values are given as means \pm SEM. Loss of ER $\alpha$ in males or AR $(\mathrm{tfm})$ but not in female mice resulted in a reduction in ash weight.

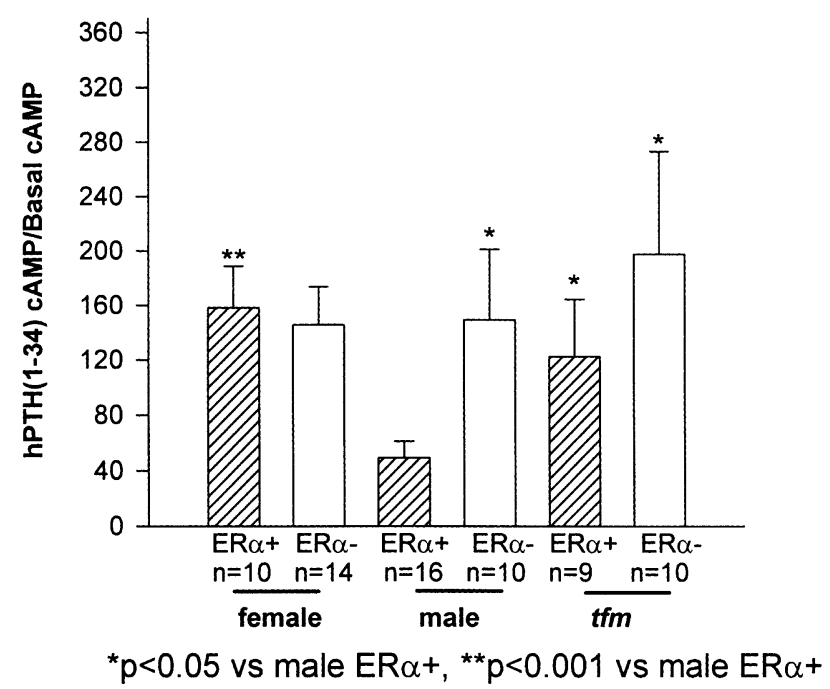

Fig. 5. PTH-stimulated cAMP levels in primary calvarial osteoblastic cells from the six genotypes of mice. Data are expressed as means \pm SEM for cultures from indicated numbers of mice/genotype. Female gender and/or loss of ER $\alpha$ or AR result in increased sensitivity to $\mathrm{PTH}$-stimulated increases in cAMP.

growth, bone mineral density, and composition of bone [35]. These effects of estrogens and androgens may be through direct stimulation of ERs and the AR, respectively. Further, androgens may express their actions indirectly by aromatization of androgens into estrogen, followed by the stimulation of ERs. Extensive work has been performed with animals to explain these effects of androgens and estrogens on skeletal metabolism [23, 36, 37].

In the present study, $t \mathrm{fm} \mathrm{ER} \alpha$ mutant mice displayed altered phenotypes in bone. Previous reports demon- strated a decrease or no change in long bone length for male and female ER $\alpha$ knockout mice [26, 38, 39]. We found no statistical difference in femur length in the absence of $E R \alpha$ in female mice. Our results for male femur length were consistent with other studies, which show a reduction in the absence of $\mathrm{ER} \alpha[40,41]$ or aromatase [42]. Moreover, $t \mathrm{fm}$ mice had the longest femurs compared to both male and female WT and ER $\alpha$ knockout mice, which was different from a previous study [22], where $t \mathrm{fm}$ rats had intermediate femur length between male and female littermates. An interesting finding in our study was an increase in tibia length of female ER $\alpha$ knockout, but not male ER $\alpha$ knockout mice. It has been speculated that increased femur and tibia size in females is due to delayed epiphyseal fusion since estrogen induces epiphyseal maturation [2]. In human cases, estrogen receptor mutations lead to a delay in epiphyseal closure with a resultant increase in the length of bone [6]. Hence, estrogen may be significant in limiting long bone development. In the rat model, the tibia increases in length at a more rapid rate in males than in females and gonadectomy reverses this sexual dimorphism, an effect that can be blocked by the administration of exogenous sex steroids [43]. Zhang et al. [44] reported that ovariectomy allowed appendicular growth to continue and orchidectomy resulted in a reduction in both appendicular and axial skeletal development [44].

Our data suggest that lack of ER $\alpha$ in females is not critical before 12 weeks. Since sex hormones start to increase at puberty they may not show their effects until this later age where estrogen inhibits long bone length. Similarly, aromatase-deficient male mice, but not females, show an absence of accelerated growth during puberty [42]. Taken together, we propose that loss of ER $\alpha$ may reverse sex steroid-dependent skeletal dimorphism for adult females. ER $\alpha$ is necessary for appendicular development in males and is the mediator of estrogenic effects on growth and maturation of the skeleton for males [40]. Loss of ER $\alpha$ causes a significant reduction in longitudinal growth for $t \mathrm{fm}$, hence $t \mathrm{fm}$ mice appear to follow the male phenotype in the appendicular skeleton. The contrast in findings of ER $\alpha$ loss of function in mice with the human condition are still an enigma but may be attributable to differences in timing of growth plate closure which occurs relatively later in life in mice.

It is clear that orchidectomized rodents and hypogonadal humans develop osteopenia [2, 4]. After androgen replacement therapy, bone mass is restored in gonadectomized male rats, and estrogen has reversed bone loss in adult orchidectomized rats $[45,46]$. Recently, Lindberg et al. [31] showed that daily $17-\beta$ estradiol injections increased trabecular bone values in orchidectomized adult male WT and ER $\beta$ knockout mice, which suggests that estrogen shows its protective 
Table 3. Relative summary of genotype changes in males ${ }^{1}$

\begin{tabular}{llll}
\hline & Loss of AR & Loss of ER $\alpha$ & Loss of AR \& ER $\alpha$ \\
\hline Femur length & $\uparrow$ & $\downarrow$ & $\downarrow$ (Slight) \\
Femur BMD & $\downarrow$ & $\downarrow$ & $\downarrow$ \\
Cortical thickness & $\downarrow$ & $\downarrow$ & $\downarrow$ \\
Trabecular bone (tibia) & $\downarrow$ & NC & $\downarrow$ \\
Trabecular bone (vertebra) & NC & NC & NC \\
\hline
\end{tabular}

$\uparrow$ increase; $\downarrow$ decrease; NC, no change

${ }^{1}$ Relative to wildtype mice

Table 4. Relative summary of genotype changes in females ${ }^{1}$

\begin{tabular}{llll}
\hline & Loss of AR & Loss of ER $\alpha$ & Loss of AR \& ER $\alpha$ \\
\hline Femur length & $\uparrow$ & $\uparrow($ Slight) & NC \\
Femur BMD & $\mathrm{NC}$ & $\mathrm{NC}$ & $\mathrm{NC}$ \\
Cortical thickness & $\uparrow$ & $\mathrm{NC}$ & $\mathrm{NC}$ \\
Trabecular bone (tibia) & $\mathrm{NC}$ & $\mathrm{NC}$ & $\mathrm{NC}$ \\
Trabecular bone (vertebra) & $\mathrm{NC}$ & $\mathrm{NC}$ & $\mathrm{NC}$ \\
\hline
\end{tabular}

$\uparrow$ increase; $\downarrow$ decrease; NC, no change

${ }^{1}$ Relative to wildtype mice

effects on trabecular bone via ER $\alpha$. They also proposed that in addition to $E R \alpha$, the AR has equal importance in the regulation of trabecular bone. In our study, we also speculate that both $\mathrm{ER} \alpha$ and AR have importance in skeletal metabolism. The DEXA data support our previous results of femur BMD and are in agreement with Vidal et al. $[39,40]$ that male WT mice have the highest femur BMD and BMC. After orchidectomy, adult male mice given estrogen have increased $\mathrm{BMD}$ and $\mathrm{BMC}$ values in male WT and ER $\beta$ knockout mice [31].

In our study, when ER $\alpha$ and/or AR were deleted, femur BMD decreased significantly which supports the notion that sex steroids exert important effects on the skeleton via $\mathrm{ER} \alpha$ as well as $\mathrm{AR}$ in males. For adult female and $\mathrm{t} f \mathrm{~m}$ mice, loss of ER $\alpha$ does not significantly have an impact on femur and tibia BMD compared to their WTs. The tfm mice seem to imitate the female gender for BMD. Further, at 4 wks of age, femurs from $\mathrm{tfm}$ mice had higher BMD compared to males and females (data not shown). However, by 12 weeks, femur BMD of males started to increase compared to tfm and females. This increase between the age of 4 and 12 weeks was much greater for males than females. This finding is in agreement with Vidal et al. [40] who stated that ERawas an important mediator of estrogenic effects on the maturation of the skeleton in male mice.

Previously, Vanderschueren et al. [22] reported that $t f m$ mice had lower vertebral ashweight than male littermates. In the present study, there was a significant reduction in femur ashweight with the loss of ER $\alpha$ but not AR compared to male WT. Interestingly, in $\mathrm{tfm}$ ER $\alpha-/-$ mice, femur ashweight decreased significantly compared to male WT and $t f m \mathrm{ER} \alpha+/+$, which may indicate that loss of $\mathrm{ER} \alpha$ causes a reduction in the mineral content of long bones. According to these changes, $\mathrm{tfm}$ mice follow a similar pattern as males for skeletal mineral content.

Recent interest has focused on receptor knockout models as well as gonadectomy models, in which the effects of sex steroids on trabecular bone have been reported. Treatment with estrogen was shown to prevent the reduction in trabecular BMD and histomorphometric parameters of bone in adult orchidectomized WT compared to ER $\alpha$ knockout males [31]. The ER $\alpha$ has also been reported to be critical for the stimulatory action of high dose estrogen on cancellous bone formation [47]

Turner et al. [48] reported that orchidectomy did not alter static bone histomorphometry measurements whereas ovariectomy increased cross-sectional areas of tibiae, and either orchidectomy or ovariectomy reduced trabecular area and trabecular bone length of tibiae in 4week-old rodents. Lindberg et al. [31] also concluded that $\mathrm{ER} \alpha$ protects trabecular bone loss in male mice and that there is redundancy with AR in the regulation of trabecular bone. In contrast, our ER $\alpha$ knockout mice did not show any significant alterations in amount of trabecular bone of the tibiae when compared to their wildtype counterparts. Further, Vanderschueren et al. demonstrated that $t \mathrm{fm}$ female rats had no difference in cancellous bone volumes for tibial histomorphometric analysis than male rats [22]. However, we found significantly decreased tibial trabecular bone area and trabecular bone length compared to male littermates. These results may indicate that $t \mathrm{fm}$ mice follow the female gender for trabecular bone. 
The impact of ER $\alpha$ and/or AR on skeletal development as compared to wildtype mice are summarized for male/tfm and female/tfm mice in Tables 3 and 4, respectively. In general, changes are more dramatic for male mice than for female mice. In female mice, loss of the AR has more impact than loss of ER $\alpha$ or the combination of $A R$ and $E R \alpha$. In male mice, loss of AR or $\mathrm{ER} \alpha$ impacts the skeleton with opposing effects on femur length but similar detrimental effects on bone mineral density and cortical bone. In the present study, numbers of osteocytes were elevated in female ER $\alpha-/-$ versus wildtype mice and also in $\mathrm{tfm}$ mice. Recently, it has been proposed that osteocytes play a role in inhibiting bone remodeling [49]. Since previous reports have indicated that loss of $\mathrm{ER} \alpha$ results in decreased bone remodeling [38], our data are in concert with this and suggest that loss of the AR may also have the same impact on bone remodeling, however, an in depth analysis of dynamic parameters is needed to verify this. Loss of ER $\alpha$ did not have an impact on trabecular bone whereas loss of AR resulted in reduced trabecular bone in the tibia but not in the vertebrae. According to these results it appears that the impact of $E R \alpha$ and $A R$ are more detrimental for males than females.

In order to better understand the cellular and molecular actions of $\mathrm{ER} \alpha$ and $\mathrm{AR}$ in bone, an in vitro evaluation of osteoblastic differentiation and receptor function was made. It is established that steroid hormones exert their effects by binding to their nuclear receptors in osteoblasts. This classic estrogen receptorsignaling pathway occurs through the entry of estrogen into the cell, interaction with ER, and transcriptional activation of estrogen-responsive genes. Recently, it has been speculated that estrogen and growth factors might share the same pathway in their signaling via plasma membrane receptors $[34,50,51]$. One of these studies reported that estrogen was found to increase cAMP in breast cancer and uterine cells as detected by enhanced membrane adenylate cyclase activity. Others have demonstrated activation of the MAPK pathway in bone or osteoblastic cells by estrogen and that this action is likely mediated through a plasma membrane receptor $[51,52]$. Our results showed that $17-\beta$ estradiol induced cAMP 1.5-2.5-fold in primary osteoblasts, a result similar among all six genotypes, suggesting that the ER or AR had no impact on this cell surface effect.

It has been suggested that sex steroids induce osteoblastic differentiation via their receptors, ER $\alpha$ and $A R$, in bone cells in vitro $[17,32,53]$. In our study, primary osteoblasts demonstrated mineralized nodule formation; however, there was no significant difference in nodule formation from cells of the different genotypes, indicating that loss of ER $\alpha$ and/or AR does not modify osteoblastic nodule formation in the absence of sex steroid hormone.

It is also clear that both in vitro and in vivo $\mathrm{PTH}$ stimulates cAMP and $c$-fos, which are early events in the
PTH signaling cascade [54]. In human trials, intermittent administration of PTH (1-34) is anabolic and increases bone density in both men and women with osteoporosis [11, 55]. However, in hypogonadal men, infusion of PTH (1-34) caused a significant increase in bone-resorbing markers but did not affect bone formation markers [13]. In our study, primary osteoblasts with ablation of $\mathrm{ER} \alpha$ and/or AR and from female WT mice had higher PTH (1-34) cAMP levels than male WT mice. We can speculate that the female chromosomal sex and loss of $\mathrm{ER} \alpha$ and/or $\mathrm{AR}$ resulted in an increased sensitivity to PTH.

In summary, these data suggest that $\mathrm{tfm}$ mice follow the male pattern for appendicular skeletal development, but imitate the female sex in bone density and trabecular bone. Further, loss of ER $\alpha$ and/or AR result(s) in increased osteoblastic sensitivity to PTH and may explain the actions of PTH noted in hypogonadal humans. These models will help to understand the altered mechanisms of skeletal metabolism, and may facilitate improved therapeutic approaches for the treatment of hypogonadal-associated osteoporosis.

Acknowledgments. This work was partially supported by the National Institutes of Health (DK 56356), the Nathan Shock Center for the Basic Biology of Aging (NIA AG 13283), the Center for Craniofacial Regeneration and TüBITAK (The Scientific and Technical Research Council of Turkey) Integrated Ph.D. Program. The authors express sincere appreciation to A. Krüst, and P. Chambon for providing the ER $\alpha-/-$ mice for these studies.

\section{References}

1. Rodan GA, Raisz LG, Bilezikian JP (2002) Pathophysiology of osteoporosis. In: Bilezikian JP, Raisz LG, Rodan GA (eds) Principles of bone biology. Academic Press, San Diego, pp 1275-1289

2. Compston JE (2001) Sex steroids and bone. Physiological Reviews 81:419-447

3. Swartz CM, Young MA (1988) Male hypogonadism and bone fracture. N Eng J Med 318:996

4. Bilezikian JP, Khosla S, Riggs BL (2002) Estrogen effects on bone in the male skeleton. In: Bilezikian JP, Raisz LG, Rodan GA (eds) Principles of bone biology. Academic Press, San Diego, pp 1467-1476

5. Vermeulen A (1990) Androgens and male senescence. In: Nieschlag E, Behre NM (eds) Testosterone:action, deficiency, substitution. Springer Verlag, Heidelberg, pp 261276

6. Smith EP, Boyd J, Frank G, Takahashi H, Cohen RM, Specker B, Williams TC, Lubahn DB, Korach KS (1994) Estrogen resistance caused by a mutation in the estrogenreceptor gene in a man. New Engl J Med 331:1056-1061

7. Rochira V, Balestrieri A, Faustini-Fustini M, Carani C (2001) Role of estrogen on bone in the human male: insights from the natural models of congenital estrogen deficiency. Mol Cell Biol 178:215-220

8. Carani C, Qin K, Simoni M, Faustini-Fustini M, Serpente S, Boyd J, Korach KS, Simpson ER (1997) Effect of testosteone and estradiol in a man with aromatase deficiency. Engl J Med 337:91-95

9. Kousteni S, Chen JR, Bellido T, et al. (2002) Reversal of bone loss in mice by nongenotropic signaling of sex steroids. Science 298:723-724 
10. Hock JM, Fitzpatrick LA, Bilezikian JP (2002) Actions of parathyroid hormone. In: Bilezikian JP, Raisz LG, Rodan GA (eds) Principles of bone biology. Academic Press, San Diego, pp 463-482

11. Neer RM, Arnaud CD, Zanchetta JR, Prince R, Gaich GA, Reginster JY, Hodsman AB, Eriksen EF, Ish-Shalom S, Genant H, Wang O, Mitlak BH (2001) Effect of parathyroid hormone (1-34) on fractures and bone mineral density in postmenopausal women with osteoporosis. N Eng J Med 10:1434-1441

12. Ma YL, Cain RL, Halladay DL, Yang X, Zeng Q, Miles RR, Chandrasekhar S, Martin TJ, Onyia JE (2001) Catabolic effects of continuous human PTH (1-38) in vivo is associated with sustained stimulation of RANKL and inhibition of osteoprotegerin and gene-associated bone formation. Endocrinology 142:4047-4054

13. Leder BZ, Smith MR, Fallon MA, Lee ML, Finkelstein JS (2001) Effects of gonadal steroid suppression on skeletal sensitivity to parathyroid hormone in men. J Clin Endocrinol Metab 86:511-516

14. Jüppner H, Abou-Samra AB, Freeman M, et al. (1991) A $\mathrm{G}$ protein-linked receptor for parathyroid hormone and parathyroid hormone-related peptide. Science 254:10241026

15. Eriksen EF, Colvard DS, Berg NJ, Graham ML, Mann KG, Spelsberg TC, Riggs BL (1988) Evidence of estrogen receptors in normal human osteoblast-like cells. Science 241:84-86

16. Abu EO, Homer A, Kusec V, Triffitt JT, Compston JE (1997) The localization of androgen receptors in human bone. J Clin Endocrinol Metab 82:3493-3497

17. Kasperk CH, Wergedal JE, Farley JR, Linkhart TA, Turner RT, Baylink DJ (1989) Androgens directly stimulate proliferation of bone cells in vitro. Endocrinology 124:1576-1578

18. Fukayama S, Tashjian AH Jr (1989) Direct modulation by estradiol of the response of human bone cells (SaOS-2) to human parathyroid hormone $(\mathrm{PTH})$ and $\mathrm{PTH}-$ related potein. Endocrinology 124:397-401

19. Fukayama S, Tashjian AH Jr (1989) Direct stimulation by androgens of the response of human bone cells (SaOS-2) to human parathyroid hormone (PTH) and PTH-related protein. Endocrinology 125:1789-1794

20. Ohno S (1971) Simplicity of mammalian regulatory systems inferred by single gene determination of sex phenotypes. Nature 234:134-137

21. Yarbrough WG, Quarmby VE, Simental JA, Joseph DR, Sar M, Lubahn DB, Olsen KL, French FS (1990) A single base mutation in the androgen receptor gene causes androgen insensitivity in the testicular feminized rat. J Biol Chem 265:8893-8900

22. Vanderschueren D, Van Herck E, Suiker A, Visser W, Schot LP, Chung K, Lucas RS, Einhorn TA, Bouillon R (1993) Bone and mineral metabolism in the androgen-resistant (testicular feminized) male rat. J Bone Miner Res 8:801-809

23. McCauley LK, Tözüm TF, Rosol TJ (2002) Estrogen receptors in skeletal metabolism: lessons from genetically modified models of receptor function. Crit Revi Eukaryotic Gene Expression 12:89-100

24. Windahl SH, Andersson G, Gustafsson JA (2002) Elucidation of estrogen receptor function in bone with the use of mouse models. TEM 13:195-200

25. Dupont S, Krust A, Gansmuller A, Dierich A, Chambon P, Mark M (2000) Effect of single and compound knockouts of estrogen receptors alpha (ERalpha) and beta (ERbeta) on mouse reproductive phenotypes. Development. 127:4277-4291

26. McCauley LK, Tözüm TF, Kozloff K, et al. (2003) Transgenic models of metabolic bone disease: impact of estrogen receptor deficiency on skeletal metabolism. Connect Tissue Res 44S1:250-263

27. Parfitt AM, Drezner MK, Glorieux FH, Kanis JA, Malluche H, Meunier PJ, Ott SM, Recker RR (1989) Bone histomorphometry: standardization of nomenclature, symbols, and units. J Bone Miner Res 2:595-610

28. McCauley LK, Koh AJ, Beecher CA, Cui Y, Rosol TJ, Franceschi RT (1996) PTH/PTHrP receptor is temporally regulated during osteoblast differentiation and is associated with collagen synthesis. J Cell Biochem 61:638-647

29. Chen H, McCauley LK, D'Silva N (2002) cAMP binding protein assay for widespread use in cell signaling studies. Biotechniques 33:66-72

30. Puchtler H, Meloan SN (1978) Demonstration of phosphates in calcium deposits: a modification of von kossa reaction. Histochemistry 56:177-185

31. Lindberg MK, Moverare S, Skrtic S, Alatalo S, Halleen J, Mohan S, Gustafsson J-A, Ohlsson C (2002) Two different pathways for the maintenance of trabecular bone in adult male mice. J Bone Miner Res 17:555-562

32. Okazaki R, Inoue D, Shibata M, Saika M, Kido S, Ooka H, Tomiyama H, Sakamoto Y, Matsumoto T (2002) Estrogen promotes early osteoblast differentiation and inhibits adipocyte differentiation in mouse bone marrow stromal cell lines that express estrogen receptor (ER) alpha or beta. Endocrinology 143:2349-2356

33. Pietras RJ, Szego CM (1999) Cell membrane estrogen receptors resurface. Nat Med 5:1330.

34. Aronica SM, Kraus WL, Katzenellenbogen BS (1994) Estrogen action via the cAMP signaling pathway: stimulation of adenylate cyclase and cAMP-regulated gene transcription. Proc Natl Acad Sci USA 91:8517-8521

35. Turner RT, Riggs BL, Spelsberg TC (1994) Skeletal effects of estrogen. Endocrine Rev 15:275-300

36. Windahl SH, Vidal O, Andersson G, Gustafsson JA, Ohlsson C (1999) Increased cortical bone mineral content but unchanged trabecular bone mineral density in female ER $\beta-/-$ mice. J Clin Invest 104:895-901

37. Vanderschueren D, Van Herck E, Geusens P, Suiker A, Visser W, Chung K, Bouillon R (1994) Androgen resistance and deficiency have different effects on the growing skeleton of the rat. Calcif Tissue Int 55:198-203

38. Sims NA, Dupont S, Krust A, Clement-Lacroix P, Minet D, Resche-Rigon M, Gaillard-Kelly M, Baron R (2002) Deletion of estrogen receptors reveals a regulatory role for estrogen receptors- $\beta$ in bone remodeling in females but not in males. Bone 30:18-25

39. Vidal O, Lindberg MK, Sävendahl L, Lubahn DB, Ritzen EM, Gustafsson JA, Ohlsson C (1999) Disproportional body growth in female estrogen receptor- $\alpha$ inactivated mice. Biochem Biophys Res Commun 265:569-571

40. Vidal O, Lindberg MK, Hollberg K, Baylink DJ, Andersson G, Lubahn DB, Mohan S, Gustafsson JA, Ohlsson C (2000) Estrogen receptor specificity in the regulation of skeletal growth and maturation in male mice. Proc Natl Acad Sci USA 97:5474-5479

41. Vandenput L, Ederveen AGH, Erben R, Stahr K, Swinnen JV, Van Herck E, Verstuyf A, Boonen S, Bouillon R, Vanderschueren D (2001) Testosterone prevents orchidectomy-induced bone loss in estrogen receptor- $\alpha$ knockout mice. Biochem Biophys Res Commun 285:70-76

42. Öz OK, Hirasawa G, Lawson J, et al. (2001) Bone phenotype of the aromatase-deficient mouse. J Steroid Biochem Mol Biol 79:49-59

43. Turner RT (1999) Mice, estrogen, and postmenopausal osteoporosis. J Bone Miner Res 14:187-191

44. Zhang XZ, Kalu DN, Erbas B, Hopper JL, Seeman E (1999) The effects of gonadectomy on bone size, mass, and volumetric density in growing rats are gender-, site-, and growth hormone-specific. J Bone Miner Res 14:802-809

45. Wakley GK, Schutte HDJ, Hannon KS, Turner RT (1991) Androgen treatment prevents loss of cancellous bone in the orchidectomized rat. J Bone Miner Res 6:325-330

46. Vandenput L, Boonen S, Van Herck E, Swinnen JV, Bouillon R, Vanderschueren D (2002) Evidence from the aged orchidectomized male rat model that 17 beta-estradiol is a more effective bone-sparing and anabolic agent 
than 5 alpha-dihydrotestosterone. J Bone Miner Res 17:2080-2086

47. McDougall KE, Perry MJ, Gibson RL, Colley SM, Korach KS, Tobias JH (2003) Estrogen receptor- $\alpha$ dependency of estrogen's stimulatory action on cancellous bone formation in male mice. Endocrinology 144:19941999

48. Turner RT, Hannon KS, Demers LM, Buechler J, Bell NH (1989) Differential effects of gonadal function on bone histomorphometry in male and female rats. J Bone Miner Res 4:557-563

49. Qiu S, Rao DS, Palnitkar S, Parfitt AM (2002) Relationships between osteocyte density and bone formation rate in human cancellous bone. Bone 31:709-711

50. Collins P, Webb C (1999) Estrogen hits surface. Nat Med 5:1130-1131

51. Kousteni S, Han L, Chen JR, Almeida M, Plotkin LI, Bellido T, Manolagas SC (2003) Kinase-mediated regulation of common transcription factors accounts for the bone-protective effects of sex steroids. J Clin Invest 111:1651-1664

52. Endoh H, Sasaki H, Maruyama K, Takeyama K, Waga I, Shimizu T, Kato S, Kawashima H (1997) Rapid activation of MAP kinase by estrogen in the bone cell line. Biochem Biophys Res Commun 235:99-102

53. Verhaar HJ, Damen CA, Duursma SA, Scheven BA (1994) A comparison of the action of progestins and estrogen on the growth and differentiation of normal adult human osteoblast-like cells in vitro. Bone 15:307-311

54. Partridge NC, Bloch SR, Pearman AT (1994) Signal transduction pathways mediating parathyroid hormone regulation of osteoblastic gene expression. J Cell Biochem 55:321-327

55. Kurland ES, Cosman F, McMahon DJ, Rosen CJ, Lindsay R, Bilezikian JP (2000) Parathyroid hormone as a therapy for idiopathic osteoporosis in men: effects on bone mineral density and bone markers. J Clin Endocrinol Metab 85:3069-3076 